\title{
Do economic policy uncertainty and environment-related technologies help in limiting ecological footprint?
}

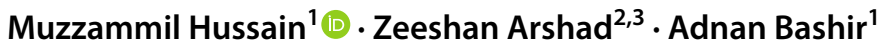

Received: 6 December 2021 / Accepted: 28 January 2022 / Published online: 16 February 2022

(c) The Author(s), under exclusive licence to Springer-Verlag GmbH Germany, part of Springer Nature 2022

\begin{abstract}
Economic policies related to energy and the environment are found uncertain in developing economies. Renewable energy sources are gradually increasing in energy structure (ES) with the adoption of environment-related technologies (ERT). However, least attention is paid to investigating the nexus of economic policy uncertainty (EPU), ERT, ES, and ecological footprint (EF). Therefore, this study is an effort to examine the EPU, ERT, ES, and interaction of EPU and ERT on EF for BRICS economies under the umbrella of the STIRPAT model. By using the data from 1992 to 2020, findings are estimated through "cross-sectional dependence (CD test); CIPS and CADF unit root test; Westerlund's co-integration; and CS-ARDL, AMG, and CCEMG." Findings unveiled the negative role of EPU on EF. Furthermore, the role of RE and ERT is positive and substantial in decreasing the environmental degradation in BRICS. Therefore, the BRICS economies are suggested to be consistent on economic policies to catch the positive impact of ERT. Findings are robust to the policy implications.
\end{abstract}

Keywords Economic policy uncertainty $\cdot$ Energy structure $\cdot$ Environment-related technologies $\cdot$ Ecological footprint . BRICS

JEL classifications $\mathrm{O} 44 \cdot \mathrm{Q} 56 \cdot \mathrm{Q} 50$

\section{Introduction}

The uncertainty associated with fiscal and monetary policies that affect the environment leads to economic policy uncertainty (Pirgaip and Dinçergök 2020). Due to global uncertainties, the economic and political stability is affected in every country of the world and vice versa, e.g., international markets are substantially influenced by the second

Responsible editor: Roula Inglesi-Lotz

Muzzammil Hussain

Muzzammil.hussain@uog.edu.pk

Zeeshan Arshad

Arshad@UA.PT

Adnan Bashir

adnan.bashir@uog.edu.pk

1 Faculty of Management and Administrative Sciences, University of Gujrat, Gujrat, Pakistan

2 University de Aveiro, Aveiro, Portugal

3 Economics Department, University of Sialkot, Sialkot, Pakistan
Gulf War in 2003 (Guidolin and la Ferrara 2010; Rigobon et al. 2005). Moreover, the COVID-19 created economic uncertainty around the globe (Baker et al. 2020). EPU may have environmental consequences in addition to economic consequences EPU, for example, encourages industries to use environmentally unfavorable manufacturing practices, resulting in environmental degradation (Amin and Dogan 2021). Furthermore, an increased EPU may reduce RE sources and environment-related technologies' (ERT) investments, and consequently, the environment may suffer.

To pay for the deprived revenue tempted by EPU, production industries employ low-cost energy sources in their manufacturing processes. As such industries' earnings increase, they invest in environment-related technologies in production processes (ERT), resulting in a better environment. The investment in ERTs can help to reduce environmental degradation (Danish and Ulucak 2020; Hussain and Dogan 2021). Furthermore, a better income level promotes RE sources, and that helps in reducing carbon emissions (Danish et al. 2019; Hussain et al. 2020a, b; Mahmood et al. 2019). It would be interesting to study the ERT, ES, and EF nexus in the presence of EPU. 
Despite the relevance of the EPU-environment nexus, there are just a few studies in the literature that examine this nexus. The majority of these studies focus only on singlecountry analysis, i.e., China and the USA (Amin and Dogan 2021; Danish and Ulucak 2020). A few studies examine the EPU-environment nexus in a panel of G-7 (Pirgaip and Dinçergök, 2020). However, they only used panel causality to estimate the results, which may unable to reflect the whole story. This is why BRICS' panel is a notable group among the world's developing countries, and it is widely highlighted in the literature (Danish and Ulucak 2020; Hasanov et al. 2021; Wang et al. 2018). The findings imply that measures promoting reduced traditional energy sources and $\mathrm{EF}$, as well as the use of renewable sources, should be implemented in BRICS nations to help mitigate the impact of EPU.

Based on this premise, this study is adding value to the existing literature of EPU-environment in the following ways: firstly, to the best knowledge of the authors, this study is first to investigate the effect of EPU, ES, and ERT on EF in BRICS by using the data from 1992 to 2020. Secondly, this study uses the most suitable econometric estimations, i.e., "CD test for cross-sectional dependence; CIPS and CADF unit root tests to check stationarity; Pedroni, Koa, Fisher, and Westerlund's co-integration; CS-ARDL, AMG, and CCEMG" techniques. These estimations can handle the problems of panel data. The rest of the paper contains a literature review section in nexus form, theoretical background, methodology, empirical results and discussions, and conclusions with policy implications.

\section{Literature review}

To understand the hypothesized linkage of considered factors, the literature is categorized into nexus in the following ways:

Firstly, the energy-environment nexus is discussed to reach a rationale. In this nexus, Rahmane et al. (2021) looked at the role played by renewable energy in the protection of the Algerian ecological footprint from 1990 to 2017. They noted a two-way causal relationship between the two aforementioned variables in their sample. They observed the ineffectiveness of RE in reducing EF. They cited the less utilization of renewable energy sources for this ineffectualness. They stressed the high usage of renewable energy for mitigating environmental degradation. Likewise, Usman and Hammar (2021) checked the effect of renewable energy consumption on the ecological footprint of the "Asia-Pacific Economic Cooperation" countries for the period 1990 to 2017. Moreover, Akif and Sinha, (2020) found that an overall increase in RE reduces the EF in their study of 24 OECD countries. Similarly, Nathaniel et al. (2020) investigated the impact of renewable energy on the ecological footprint of CIVETS countries from 1990 to 2014. They noted that though renewable energy enhances environmental quality and reduces ecological footprints, this effect is insignificant. They believed that CIVETS countries need to invest more in RE sources to increase environmental quality. Furthermore, in an important study by Ulucak and Khan (2020), it is concluded that RE decreases EF in their sample of BRICS countries. So, the positive role of RE in protecting the environment and its quality is observed in this study. They arrived at these conclusions by applying fully modified ordinary least squares and dynamic ordinary least squares for 1992 to 2016. They also seconded the commitment of BRICS countries in achieving sustainable development goals by renewable energy technologies. Alola et al. (2019) explored the dynamic impact of RE on the EF of 16 European Union countries from 1997 to 2014. They highlighted the RE usage in protecting the environment. Based on these arguments, it is further recommended that ES should be examined in the presence of uncertain economic policies in the BRICS.

Secondly, the EPU-environment nexus' literature is investigated to draw conclusive remarks for the BRICS's economic policies. There is a wealth of literature on the relationship between EPU and $\mathrm{CO}_{2}$ emission (Danish et al. 2020a; Pirgaip and Dinçergök 2020; Yu et al. 2021; Zakari et al. 2021). However, there are a handful of studies using EF as a measure of environmental quality. For example, Anser et al. (2021) investigated the effect of economic policy uncertainty on the EF of five emerging states from 1995 to 2015. They concluded that EPU lessens environmental degradation in their study. They were of the view that EPU reduces the use of energy and other pollution-based materials. This in turn had a positive effect on EF. On similar grounds, Chu and Le (2021) explored the effect of EPU on the EF of G7 countries for the period from 1997 to 2015. They concluded that high economic policy uncertainty causes economic slow-down and forces organizations to use cheap and harmful sources of energy. They spend less on measures to combat environmental protection. They were of the view that economic policy uncertainty reduces the ecological footprint. In another study, explored the impact of economic policy uncertainty on the ecological footprint of the top ten income producer countries from tourism from 1995 to 2015. They found that EPU enhances the EF in their sample. According to the root cause, the reason for this negative impact lies in uncertain trade and stock market activities. They were also of the view that during uncertain times, there is less emphasis on environmental protection measures. Therefore, it is interesting to further investigate the role of EPU-environment nexus by considering the role of ERT in the BRICS economies.

Thirdly, literature is scarce on the impact of environmental technologies and ecological footprint. The impact of technological development on the EF and carbon emission of big emerging countries from 1995 to 2016 using 
second-generation panel data techniques is examined (Destek and Manga 2021). Moreover, Hussain and Dogan (2021) checked the effect of environmental technologies on the ecological footprint in BRICS for the period 1992 to 2016. They observed that the increase in investment in ERT reduces environmental degradation. They advocated the positive role of ERT in the reduction of EF consumption per capita. However, they stressed the need for more investment in reducing EF levels in BRICS. On this premise in the light of controversial literature, further investigation of the phenomenon is necessary. Therefore, this study is reinvestigating the nexus in BRICS economies. Interestingly, the role of EPU, ES, and ERT on EF is examined, which was silent in the literature. So, this study is adding a little knowledge to the existing literature. The theoretical base and the methodology section provided the theoretical and empirical evidence in the following sections.

\section{Theoretical background and model construction}

The Stochastic Impacts by Regression (STIRPAT) model is an important model which is commonly employed for problem-solving. In literature, the STIRPAT procedure is used in numerous studies to estimate the influence of different factors on carbon emissions, in Europe, the long- and short-run impact of energy, economic, and social factors on the environment (Chen et al. 2021; Ghazali and Ali 2019; Hussain et al. 2020a, b; Pham et al. 2020). Moreover, many studies followed the above-mentioned model to validate the linkage of environmental proxies with income level, population, and other relevant factors (Amin and Dogan 2021). Therefore, EPU, ES, ERT, and EF are assumed to be connected by controlling the population and income level in BRICS. Based on the recognized population, affluence, and technology-STIRPAT-theory framework, we offer the following model:

$E F=a_{0}+\beta_{1} \mathrm{Y}+\beta_{2} \mathrm{P}+\beta_{3} \mathrm{ES}+\beta_{4} \mathrm{ERT}+\beta_{5} \mathrm{EPU}+\mu$

where $E F$ is an abbreviation used for ecological footprint measured as ecological footprints consumption per capita and $Y$ represents the income level measured as GDP. $P$ is the total population of a country every year. ES is used for energy structure which is a share of renewable energy in the total energy consumption. ERT is representing an investment in the production and processing of goods and services by using environment-related technologies which are sustainable technologies used in the production and processing of goods without harming the environment. $E P U$ is economic policy uncertainty, and as per the literature support, the role of $E P U$ is proposed to be negative toward environmental degradation. The annual data from 1992 to 2020 is used to estimate the proposed model for the BRICS economies. Furthermore, the measurements and sources of every variable are briefed in Table 1.

\section{Econometric methodology}

Based on the panel data requirements and diagnostics, the second-generation econometric techniques are suitable estimates for the proposed linkages: cross-sectional dependence test and correlation. After the CSD test (Pesaran 2015), it is necessary to identify the stationarity of the variables. For this purpose, the CADF (Pesaran 2007) and CIPS tests are selected which are capable of managing the CSD problem. Subsequently, co-integration estimation is used (Kao 1999; Pedroni 2001; Westerlund 2007). Eventually, the CSD problem is dealt with using a newly CS-ARDL technique (Chudik et al. 2015; Ghazali and Ali 2019). The benefit of using the "cross-sectional autoregressive distributed lag" estimation is that it can handle the problem of cross-sectional dependence and endogeneity (Hussain et al. 2020a, b; Khan et al. 2020). The model for "cross-section augmented autoregressive distributive lag (CS-ARDL)" is as follows:

$\Delta E_{i t}=A_{i t}+\sum_{I=1}^{q} \varnothing_{i I} \Delta E_{i, t-I}+\sum_{I=0}^{q} \varphi_{i I}^{*} M_{i, t-1}+\sum_{I=0}^{q} \partial_{i I}^{*} \bar{X}_{i, t-1}+\mu_{i t}$

where $\bar{X}_{i}, \Delta \bar{E}_{i t}$, and $\Delta \bar{M}_{i t}$ are for the averages of crosssections of dependent and independent variables. Furthermore, the robustness of results is also checked by using the, "augmented mean group" (AMG) and "common correlated effect mean group" (CCEMG) estimators; these techniques are equally well-suited to manage CSD and heterogeneity

Table 1 Variables' details

\begin{tabular}{llll}
\hline Abrev & Indicator name & Measurement & Source \\
\hline EF & Ecological footprint & Consumption per capita & GFN \\
Y & GDP & US dollar & WDI \\
P & Population & Total population & WDI \\
ES & Energy structure & The share of renewable energy consump- & EIA \\
& & tion in total energy & OECD stats \\
ERT & Environment-related technologies & Investment in ERT & Economic policy \\
EPU & Economic policy uncertainty & Bakers' 2016 measurement scale of EPU & uncertainty \\
& & & index \\
\hline
\end{tabular}


problems (Eberhardt and Bond 2009; Hussain and Dogan 2021; Hussain and Khan 2021).

\section{Empirical results and discussions}

To follow the recommended procedure, the results start with basic statistics (correlation and CD test). In the first part of Table 2, correlation results are given. According to the results, all the considered factors, i.e., Y, P, ES, ERT, and EPU, are significantly correlated with ecological footprints. In the last part of Table 2, the results of cross-sectional dependence (CD test) are given. The results report the problem of the crosssectional issue in the panel data. It means that the data is showing the inter-dependence of cross-sections. It may be due to the similar characteristics of BRICS economies.

In the presence of "cross-sectional dependence problem" in the data, the next procedure is to examine the unit root problem. The results of CIPS and CADF unit root tests' results are reported in Table 3. These second-generation unit root estimations are recommended for panel data with CD problems (Danish and Ulucak 2020; Hasanov et al. 2021). According to the reported results, the variable which is not stationary at the level, after taking the first difference, becomes stationary. Overall, all the variables are stationary, which is a necessary condition for the applied estimations (CS-ARDL, AMG, CCEMG).

After the confirmation of stationarity, the next suitable step is to check the co-integration among the sampled variables. For the pursuit of this goal, first- and second-generation co-integration (Kao 1999; Pedroni 1999, 2004; Westerlund 2007) tests are applied, and the results are reported in Table 4. According to the results, EF, Y, P, ERT, ES, and EPU are co-integrated. The results are confirmed by all the estimations. It is an indication of the robustness of the results. It means that the said variable has a long-run relationship (Ali et al. 2021; Hussain et al. 2020a, b).

After confirmation of the co-integration by the first- and second-generation co-integration techniques, the next suitable step is to estimate the short- and long-run association of the

Table 2 Correlation and CD test

\begin{tabular}{lllllll}
\hline Variables & LNEF & LNY & LNP & LNES & LNERT & LNEPU \\
\hline LNEF & 1 & & & & & \\
LNY & 0.5761 & 1 & & & & \\
LNP & -0.7059 & 0.2820 & 1 & & & \\
LNES & 0.4654 & 0.6879 & 0.2406 & 1 & & \\
LNERT & 0.5575 & 0.6097 & -0.43233 & 0.2743 & 1 & \\
LNEPU & 0.2589 & 0.4012 & -0.02266 & 0.4442 & 0.0058 & 1 \\
CD test & $-3.1386^{* * *}(0.00)$ & $14.0077^{* * *}(0.00)$ & $2.3820^{* * *}(0.01)$ & $9.4216^{* * *}(0.05)$ & $-1.9471 *(0.09)$ & $7.7960^{* * * *(0.00)}$ \\
\hline
\end{tabular}

The authors own calculations. In the case of CD test, $P$ values are reported in parenthesis, and ***, **, and $*$ represents $1 \%, 5 \%$, and $10 \%$ levels of significance

Table 3 Unit root tests

\begin{tabular}{|c|c|c|c|c|c|c|c|c|}
\hline \multirow[b]{3}{*}{ Variables } & \multirow{2}{*}{\multicolumn{2}{|c|}{ CIPS }} & \multicolumn{6}{|l|}{ CADF } \\
\hline & & & \multicolumn{3}{|c|}{ Without trend } & \multicolumn{3}{|c|}{ With trend } \\
\hline & Without trend & With trend & T-bar & Z-t-tilde-bar & $P$ value & T-bar & Z-t-tilde-bar & $P$ value \\
\hline LNEF & -1.46 & -2.88 & -2.90 & -2.62 & $0.004^{*}$ & -2.97 & -2.73 & $0.054 *$ \\
\hline$\Delta \mathrm{LNEF}$ & -4.87 & -5.42 & -3.31 & -3.57 & $0.000^{*}$ & 3.02 & -1.72 & $0.042 *$ \\
\hline LNY & -1.25 & -0.87 & -0.08 & 3.87 & 1.000 & -1.41 & 2.16 & 0.985 \\
\hline$\Delta \mathrm{LNY}$ & -5.57 & -5.28 & -2.38 & -1.42 & $0.076^{*}$ & -2.54 & -0.56 & $0.028 *$ \\
\hline LNP & -2.65 & -1.31 & -2.61 & -1.97 & $0.024 *$ & -3.19 & -2.12 & $0.017 *$ \\
\hline$\Delta \mathrm{LNP}$ & -2.98 & -3.69 & -1.44 & 0.73 & $0.009^{*}$ & -2.97 & -1.59 & $0.055^{*}$ \\
\hline LNES & -1.20 & -2.60 & -1.53 & 0.51 & 0.69 & -2.15 & 0.37 & 0.644 \\
\hline$\Delta \mathrm{LNES}$ & -5.73 & -6.16 & -4.57 & -6.48 & $0.000^{*}$ & -4.38 & -4.97 & $0.000 *$ \\
\hline LNERT & -2.25 & -2.15 & -1.98 & -0.51 & 0.302 & -1.67 & 1.53 & 0.937 \\
\hline$\Delta$ LNERT & -5.64 & -6.16 & -4.77 & -6.94 & $0.000^{*}$ & -5.35 & -7.32 & $0.000 *$ \\
\hline LNEPU & -1.72 & -2.24 & -2.031 & -0.62 & 0.26 & -2.19 & 0.28 & 0.611 \\
\hline$\Delta \mathrm{LNEPU}$ & -5.67 & -5.84 & -4.49 & -6.31 & $0.000 *$ & -4.49 & -5.26 & $0.000 *$ \\
\hline
\end{tabular}

$*$ is the level of significance 
Table 4 Pedroni, Kao, and Fisher co-integration analysis

\begin{tabular}{|c|c|c|c|c|c|c|c|c|}
\hline \multicolumn{4}{|l|}{ Pedroni test } & \multicolumn{2}{|l|}{ Kao residual } & \multicolumn{3}{|l|}{ Johansen Fisher } \\
\hline & & Statistic & Weighted stat & T-stat & Prob & $\begin{array}{l}\text { No of co-integra- } \\
\text { tion }\end{array}$ & Trace & Max eigen test \\
\hline \multirow[t]{4}{*}{ Within-dimension } & Panel v & $\begin{array}{l}0.7515 \\
(0.22)\end{array}$ & $\begin{array}{l}-0.4322 \\
(0.63)\end{array}$ & $-1.8401^{* * *}$ & 0.0003 & None & $\begin{array}{l}177.2^{* * *} \\
(0.00)\end{array}$ & $\begin{array}{l}77.84^{* * *} \\
(0.00)\end{array}$ \\
\hline & Panel rho & $\begin{array}{l}-0.606 \\
(0.26)\end{array}$ & $\begin{array}{l}-0.1786 \\
(0.43)\end{array}$ & & & At most 1 & $\begin{array}{l}113.8^{* * * *} \\
(0.00)\end{array}$ & $\begin{array}{l}62.10^{* * *} \\
(0.00)\end{array}$ \\
\hline & Panel PP & $\begin{array}{l}-5.2189^{* * *} \\
(0.00)\end{array}$ & $\begin{array}{l}-4.2627^{* * *} \\
(0.00)\end{array}$ & & & At most 2 & $\begin{array}{l}65.65^{* * *} \\
(0.00)\end{array}$ & $\begin{array}{l}29.13 * * * \\
(0.00)\end{array}$ \\
\hline & Panel ADF & $\begin{array}{l}-2.2965^{* * *} \\
(0.01)\end{array}$ & $\begin{array}{l}-4.7051^{* * *} \\
(0.00)\end{array}$ & & & At most 3 & $\begin{array}{l}43.49^{* * *} \\
(0.00)\end{array}$ & $\begin{array}{l}25.23^{\text {****}} \\
(0.00)\end{array}$ \\
\hline \multirow[t]{3}{*}{$\begin{array}{l}\text { Between-dimen- } \\
\text { sion }\end{array}$} & Group rho & $\begin{array}{l}0.4820 \\
(0.61)\end{array}$ & & & & At most 4 & $\begin{array}{l}28.23^{* * *} \\
(0.00)\end{array}$ & $\begin{array}{l}19.42^{* *} \\
(0.03)\end{array}$ \\
\hline & Group PP & $\begin{array}{l}-4.6666^{* * *} \\
(0.00)\end{array}$ & & & & At most 5 & $\begin{array}{l}27.74 * * * \\
(0.00)\end{array}$ & $\begin{array}{l}27.74 * * * \\
(0.00)\end{array}$ \\
\hline & Group ADF & $\begin{array}{l}-4.1626^{* * * *} \\
(0.01)\end{array}$ & & & & & & \\
\hline \multicolumn{9}{|c|}{ Westerlund co-integration test } \\
\hline \multicolumn{2}{|l|}{ Statistics } & Value & $Z$ value & $P$ value & Robust $P$ value & & & \\
\hline \multicolumn{2}{|l|}{$\mathrm{Gt}$} & -7.058 & -6.873 & 0.06 & $0.00^{* * * *}$ & & & \\
\hline \multicolumn{2}{|l|}{$\mathrm{Ga}$} & -3.222 & 3.213 & 1.00 & $0.10^{*}$ & & & \\
\hline \multicolumn{2}{|l|}{$\mathrm{Pt}$} & -8.419 & -3.617 & 0.03 & $0.00^{* * *}$ & & & \\
\hline \multicolumn{2}{|l|}{$\mathrm{Pa}$} & -4.679 & 2.145 & 0.98 & $0.06^{*}$ & & & \\
\hline
\end{tabular}

$* * *, * *$, and $*$ represent $1 \%, 5 \%$, and $10 \%$ levels of significance

factors of the model. The results of CS-ARDL, AMG, and CCEMG are reported in Table 5. The income level Y is statistically significant with a positive coefficient $(0.415)$ in the long run. It means that a $1 \%$ change in income level can change the ecological footprints by $0.415 \%$ in the BRICS economies in the long run. In other words, with an increasing level of GDP in these economies, the level of environmental degradation is increasing. These results are supported by literature (Danish et al. 2020a; Ghazali and Ali 2019; Haldar and Sethi 2022; Hussain et al. 2020a, b). It is observed that in growing economies like the BRICS, the income level is a major contributor to environmental degradation. The next independent variable is population, which is not significantly affecting the ecological footprint in CS-ARDL and AMG results. However, with a positive coefficient, $\mathrm{P}$ is indicating the significant linkage of the $\mathrm{P}$ with $\mathrm{EF}$ in CCEMG results. These results are aligned
Table 5 Augmented mean group (AMG), common correlated effect means group (CCEMG), and CS-ARDL

\begin{tabular}{|c|c|c|c|c|c|c|}
\hline \multirow{3}{*}{$\begin{array}{l}\text { Dependent variable } \\
\text { Methods } \\
\text { Variables }\end{array}$} & \multicolumn{6}{|c|}{ Ecological footprint } \\
\hline & \multicolumn{2}{|l|}{ AMG } & \multicolumn{2}{|l|}{ CCEMG } & \multicolumn{2}{|l|}{ CS-ARDL } \\
\hline & Coefficient & Prob & Coefficient & Prob & Coefficient & Prob \\
\hline \multicolumn{7}{|l|}{ Long-run coefficients } \\
\hline LNY & $0.7641 * *$ & 0.0400 & $0.5371 * * *$ & 0.0012 & $0.4159 * *$ & 0.0243 \\
\hline LNP & 0.7272 & 0.6700 & $0.2850 *$ & 0.0900 & 0.5533 & 0.1121 \\
\hline LNES & $-0.0667 * *$ & 0.0500 & $-0.0392 * * *$ & 0.0081 & $-0.0416^{*}$ & 0.0628 \\
\hline LNERT & $-0.2371 * *$ & 0.0300 & $-0.2741 * * *$ & 0.0021 & $-0.0135^{* *}$ & 0.0451 \\
\hline LNEPU & $0.1502 *$ & 0.0730 & $0.1159 *$ & 0.0243 & $0.2122 *$ & 0.0812 \\
\hline \multicolumn{7}{|l|}{ Short-run coefficients } \\
\hline $\mathrm{D}(\mathrm{LNY})$ & & & & & 1.2825 & 0.233 \\
\hline $\mathrm{D}(\mathrm{LNP})$ & & & & & $0.9247 *$ & 0.092 \\
\hline D(LNES) & & & & & -0.1040 & 0.842 \\
\hline $\mathrm{D}($ LERT $)$ & & & & & $-0.0234^{*}$ & 0.0651 \\
\hline D(LNEPU) & & & & & 0.1543 & 0.247 \\
\hline
\end{tabular}

$*$, **, and *** represent $10 \%, 5 \%$, and $1 \%$ levels of significance 
with the literature (Amin and Dogan 2021; Pham et al. 2020). It means that the population is substantially increasing the level of ecological footprint in BRICS.

Energy structure is negatively affecting the EF significantly. The coefficient is -0.041 , which means that a $1 \%$ increase in renewable energy can decrease the level of EF by $0.041 \%$ in the BRICS. These results are verified by the AMG and CCEMG. It is notable here that the increasing share of renewables in the total energy structure can help to reduce environmental degradation. In easy words, with the investment in renewable resources of energy, sustainable development can be achieved in the BRICS region. These results are also endorsed by the previous studies (Adedoyin et al. 2021a, b; Amin and Dogan 2021; Danish et al. 2017).

The coefficient of ERT is found negative and significant with a coefficient of 0.013 . It refers to the fact that a $1 \%$ increase in the investment of ERTs can help to decrease the EF by $0.013 \%$ in the long run in the BRICS economies. This result is also supported by AMG and CCEMG, declaring it robust. This phenomenon is leading to logic that an increase in the investment in production and processing of environment-related technologies can help to decrease the dangerous emissions in the environment and ultimately the ecological footprint in the long run. These results are also supported by Danish and Ulucak (2020); Hussain and Dogan (2021); and Hussain and Khan (2021).

In the case of EPU, the results report the positive and significant effect of EPU on EF. In the coefficient empirical value of 0.212, it indicates the deteriorating role of EPU toward EF. Empirically, $1 \%$ change in EPU is increasing EF by $0.212 \%$ in the BRICS in the long run. Moreover, this outcome is also endorsed by the AMG and CCEMG. It led to the phenomenon that uncertain economic policies are detrimental to the environment. This outcome is also supported by the literature of individual country analysis (Amin and Dogan 2021; Danish et al. 2020a; Godil et al. 2020). The results of pair-wise causality are reported in Table 6. Bidirectional causality is reported in Y, P, and EF. It means the income level, population, and environmental degradation are having bidirectional linkage and affect each other. On the other hand, unidirectional causality was reported among ERT and EF, ES and EF, EPU, and EF. It refers to the indication that ERT, ES, and EPU are affecting EF; however, $\mathrm{EF}$ is not causing any effect on these factors. Furthermore, no causality is reported in $\mathrm{Y}$ and ERT, ES, and P.

\section{Conclusion and policy implications}

In this study, the effect of economic policy uncertainty is tested on ecological footprints under the STIRPAT model along with the energy structure and investment in environment-related technologies. The latest available annual data from 1992 to 2020 is used to test the hypothesized nexus by
Table 6 Pair-wise causality test

\begin{tabular}{|c|c|c|c|}
\hline Null hypothesis & W-stat & $\mathrm{Z}$ bar-stat & Prob \\
\hline $\begin{array}{l}\text { LNY does not homogeneously cause } \\
\text { LNEF }\end{array}$ & 9.26852 & 6.49854 & 8.E-11 \\
\hline LNEF does not cause LNY & 6.21453 & 3.69081 & 0.0002 \\
\hline LNP does not cause LNEF & 9.37159 & 6.59330 & 4.E-11 \\
\hline LNEF does not cause LNP & 10.2686 & 7.41796 & 1.E-13 \\
\hline LNES does not cause LNEF & 1.89600 & -0.27948 & 0.7799 \\
\hline LNEF does not cause LNES & 5.06482 & 2.63381 & 0.0084 \\
\hline LNERT does not cause LNEF & 5.68402 & 3.20308 & 0.0014 \\
\hline LNEF does not cause LNERT & 2.46549 & 0.24408 & 0.8072 \\
\hline LNEPU does not cause LNEF & 2.76861 & 0.52276 & 0.6011 \\
\hline LNEF does not cause LNEPU & 6.56487 & 4.01290 & 6.E-05 \\
\hline LNP does not cause LNY & 6.25244 & 3.72567 & 0.0002 \\
\hline LNY does not cause LNP & 7.24839 & 4.64130 & 3.E-06 \\
\hline LNES does not cause LNY & 3.17612 & 0.89741 & 0.3695 \\
\hline LNY does not cause LNES & 4.22328 & 1.86013 & 0.0629 \\
\hline LNERT does not cause LNY & 2.01416 & -0.17086 & 0.8643 \\
\hline LNY does not cause LNERT & 3.02149 & 0.75525 & 0.4501 \\
\hline LNEPU does not cause LNY & 3.62497 & 1.31006 & 0.1902 \\
\hline LNY does not cause LNEPU & 6.17603 & 3.65542 & 0.0003 \\
\hline LNES does not cause LNP & 3.55949 & 1.24986 & 0.2113 \\
\hline LNP does not cause LNES & 3.26444 & 0.97861 & 0.3278 \\
\hline LNERT does not cause LNP & 3.88902 & 1.55282 & 0.1205 \\
\hline LNP does not cause LNERT & 6.76828 & 4.19991 & 3.E-05 \\
\hline LNEPU does not cause LNP & 7.34343 & 4.72868 & 2.E-06 \\
\hline LNP does not cause LNEPU & 3.69438 & 1.37388 & 0.1695 \\
\hline LNERT does not cause LNP & 3.88902 & 1.55282 & 0.0905 \\
\hline LNP does not cause LNERT & 6.76828 & 4.19991 & 3.E-05 \\
\hline LNEPU does not cause LNP & 7.34343 & 4.72868 & 2.E-06 \\
\hline LNP does not cause LNEPU & 3.69438 & 1.37388 & 0.1695 \\
\hline LNERT does not cause LNES & 2.70046 & 0.46011 & 0.6454 \\
\hline LNES does not cause LNERT & 1.52706 & -0.61867 & 0.5361 \\
\hline LNEPU does not cause LNES & 2.73643 & 0.49318 & 0.6219 \\
\hline LNES does not cause LNEPU & 6.28704 & 3.75747 & 0.0002 \\
\hline LNEPU does not cause LNERT & 1.01619 & -1.08835 & 0.2764 \\
\hline LNERT does not cause LNEPU & 1.88872 & -0.28618 & 0.7747 \\
\hline
\end{tabular}

Bold values are insignificant

applying CD test; CIPS and CADF unit roots tests; first- and second-generation co-integration tests (Kao 1999; Pedroni 1999, 2004; Westerlund 2007); and CS-ARDL, AMG, and CCEMG estimations. Findings unveil the supportive role of ES and ERT in limiting the environmental degradation in BRICS. However, the EPU is found to be harmful to the environment. Furthermore, unidirectional causality is also evident in ES, ERT, and EPU toward EF.

Based on the empirical findings, some important policy implications can be suggested. Firstly, energy structure remains a major contributor toward reducing the ecological footprint. Therefore, the replacement of traditional energy 
sources with renewable energy sources may help to reduce the level of environmental degradation in the BRICS. Secondly, the ERT is found to substantially reduce the EF. The BRICS may increase investment in the production and processing of ERTs to realize the benefit. They may subsidize the industrial production that opts for the ERTs to enhance sustainable growth. In this way, the BRICS can move toward sustainable development. Thirdly, the BRICS countries' policymakers should pay attention to minimizing EPU, because EPU is substantially increasing the level of EF. By controlling the EPU, the goal of a sustainable environment can be eased. Therefore, to implement the ERTs, the BRICS need an immediate plan that may help to reduce the economic policy uncertainty.

This study also has some limitations, which may lead to new research agenda. Due to limited data availability, this study is restricted to 29 years. Future studies may use longer data to other parts of the world which may bring a different outcome. Moreover, the economic policy of the high-income countries may behave differently. Therefore, the study of EPU and EF in high-income economies may bring more interesting results. Additionally, the role of EPU may reflect differences in different economies, so the country-level study of EPU may bring interesting results.

Author contribution Data collection and analysis are done by Muzzammil Hussain, Zeeshan Arshad, and Adnan Bashir. Moreover, Adnan Bashir supervises the paper. The first draft of the manuscript was written by Muzzammil Hussain, and all authors commented on previous versions of the manuscript. All authors approved the final manuscript for publication.

Data availability The data used in this paper can be provided on demand.

\section{Declarations}

Ethics approval and consent to participate The authors are hereby ready to give their consent on ethical approval for the participation in this paper.

Consent for publication The authors has no objection if the paper is considered for publication in ESPR journal.

Competing interests The authors declare no competing interests.

\section{References}

Adedoyin FF, Nathaniel S, Adeleye N (2021a) An investigation into the anthropogenic nexus among consumption of energy, tourism, and economic growth: do economic policy uncertainties matter? Environ Sci Pollut Res 28(3):2835-2847. https://doi.org/10.1007/ s11356-020-10638-x

Adedoyin FF, Ozturk I, Agboola MO, Agboola PO, Bekun FV (2021) The implications of renewable and non-renewable energy generating in Sub-Saharan Africa: the role of economic policy uncertainties. Energy Policy 150(December 2020):112115. https:// doi.org/10.1016/j.enpol.2020.112115

Akif M, Sinha A (2020) Renewable, non-renewable energy consumption, economic growth, trade openness and ecological footprint: evidence from organisation for economic co-operation and development countries. J Clean Prod 242:118537. https://doi.org/10. 1016/j.jclepro.2019.118537

Al-mulali U, Adebola S, Sheau-ting L, Ozturk I (2016) Does moving towards renewable energy causes water and land inefficiency? An empirical investigation. Energy Policy 93:303-314. https:// doi.org/10.1016/j.enpol.2016.03.023

Ali S, Dogan E, Chen F, Khan Z (2021) International trade and environmental performance in top ten-emitters countries: the role of eco-innovation and renewable energy consumption. Sustain Dev 29(2):378-387. https://doi.org/10.1002/sd.2153

Alola AA, Victor F, Asumadu S (2019) Science of the total environment dynamic impact of trade policy, economic growth, fertility rate, renewable and non-renewable energy consumption on ecological footprint in Europe. Sci Total Environ 685:702-709. https://doi.org/10.1016/j.scitotenv.2019.05.139

Amin A, Dogan E (2021) The role of economic policy uncertainty in the energy-environment nexus for China: evidence from the novel dynamic simulations method. J Environ Manage 292:112865. https://doi.org/10.1016/J.JENVMAN.2021.112865

Anser MK, Syed QR, Lean HH, Alola AA, Ahmad M (2021) Do economic policy uncertainty and geopolitical risk lead to environmental degradation? Evidence from Emerging Economies

Baker SR, Bloom N, Davis SJ, Terry SJ (2020) COVID-induced economic uncertainty. Retrieved from www.worlduncertaintyindex. com

Chen F, Hussain M, Khan JA, Mir GM, Khan Z (2021) Voluntary disclosure of greenhouse gas emissions by cities under carbon disclosure project: a sustainable development approach. Sustain Dev, sd.2169. https://doi.org/10.1002/sd.2169

Chu LK, Le NTM (2021) Environmental quality and the role of economic policy uncertainty, economic complexity, renewable energy, and energy intensity: the case of G7 countries. Environ Sci Pollut Res, (2019). https://doi.org/10.1007/s11356-021-15666-9

Chudik A, Mohaddes DK, Pesaran MH (2015) Federal Reserve Bank of Dallas Globalization and Monetary Policy Institute longrun effects in large heterogenous panel data models with crosssectionally correlated errors *. Retrieved from http://www.dalla sfed.org/assets/documents/institute/wpapers/2015/0223.pdf

Danish MAB, Mahmood N, Zhang JW (2019) Effect of natural resources, renewable energy and economic development on $\mathrm{CO}$ 2 emissions in BRICS countries. Sci Total Environ 678:632638. https://doi.org/10.1016/j.scitotenv.2019.05.028

Danish, Ulucak R (2020) How do environmental technologies affect green growth? Evidence from BRICS economies. Sci Total Environ 712:136504. https://doi.org/10.1016/j.scitotenv.2020. 136504

Danish, Ulucak R, Khan SUD (2020) Determinants of the ecological footprint: role of renewable energy, natural resources, and urbanization. Sustain Cities Soc 54:101996. https://doi.org/10. 1016/j.scs.2019.101996

Danish, Zhang B, Wang B, Wang Z (2017) Role of renewable energy and non-renewable energy consumption on EKC: evidence from Pakistan. J Clean Prod 156:855-864. https://doi.org/10.1016/j. jclepro.2017.03.203

Destek MA, Manga M (2021) Technological innovation, financialization, and ecological footprint: evidence from BEM economies. Environ Sci Pollut Res 28(17):21991-22001. https://doi.org/10. 1007/s11356-020-11845-2

Eberhardt M, Bond S (2009) Cross-section dependence in nonstationary panel models: a novel estimator 
Ghazali A, Ali G (2019) Investigation of key contributors of CO 2 emissions in extended STIRPAT model for newly industrialized countries: a dynamic common correlated estimator (DCCE) approach. Energy Rep 5:242-252. https://doi.org/10.1016/j. egyr.2019.02.006

Godil DI, Sarwat S, Sharif A, Jermsittiparsert K (2020) How oil prices, gold prices, uncertainty and risk impact Islamic and conventional stocks? Empirical evidence from QARDL technique. Resour Policy 66:101638. https://doi.org/10.1016/j.resourpol. 2020.101638

Guidolin M, la Ferrara E (2010) The economic effects of violent conflict: evidence from asset market reactions. 47(6), 671-684. https://doi.org/10.1177/0022343310381853

Haldar A, Sethi N (2022) Environmental effects of information and communication technology - exploring the roles of renewable energy, innovation, trade and financial development. Renew Sustain Energy Rev 153:111754. https://doi.org/10.1016/J. RSER.2021.111754

Hasanov FJ, Khan Z, Hussain M, Tufail M (2021) Theoretical framework for the carbon emissions effects of technological progress and renewable energy consumption. Sustain Dev, sd.2175. https://doi.org/10.1002/sd.2175

Hussain M, Dogan E (2021) The role of institutional quality and environment-related technologies in environmental degradation for BRICS. J Clean Prod 304:127059. https://doi.org/10.1016/j. jclepro.2021.127059

Hussain M, Khan JA (2021) The nexus of environment-related technologies and consumption-based carbon emissions in top five emitters: empirical analysis through dynamic common correlated effects estimator. Environ Sci Pollut Res 2021:1-10. https://doi.org/10.1007/S11356-021-15333-Z

Hussain M, Mir GM, Usman M, Ye C, Mansoor S (2020a) Analysing the role of environment-related technologies and carbon emissions in emerging economies: a step towards sustainable development. Environ Technol 1-24. https://doi.org/10.1080/ 09593330.2020 .1788171

Hussain M, Usman M, Khan JA, Tarar ZH, Sarwar MA (2020b) Reinvestigation of environmental Kuznets curve with ecological footprints: empirical analysis of economic growth and population density. J Public Affairs (July). https://doi.org/10.1002/pa. 2276

Kao C (1999) Spurious regression and residual-based tests for cointegration in panel data. J Econ 90(1):1-44. https://doi.org/10. 1016/S0304-4076(98)00023-2

Khan Z, Ali M, Jinyu L, Shahbaz M, Siqun Y (2020) Consumptionbased carbon emissions and trade nexus: evidence from nine oil exporting countries. Energy Econ 89:104806. https://doi.org/10. 1016/j.eneco.2020.104806

Mahmood N, Wang Z, Hassan ST (2019) Renewable energy, economic growth, human capital, and CO 2 emission: an empirical analysis

Nathaniel S, Nwodo O, Sharma G, Shah M, Nathaniel S (2020) Renewable energy, urbanization, and ecological footprint linkage in CIVETS. 19616-19629

Pedroni P (1999) Critical values for cointegration tests in heterogeneous panels with multiple regressors. Oxford Bull Econ Stat 61(s1):653-670. https://doi.org/10.1111/1468-0084.0610s1653

Pedroni P (2001) Purchasing power parity tests in cointegrated panels

Pedroni P (2004) Panel cointegration: asymptotic and finite sample properties of pooled time series tests with an application to the
PPP hypothesis. Economet Theor 20(3):597-625. https://doi. org/10.1017/S0266466604203073

Pesaran MH (2007) A simple panel unit root test in the presence of cross-section dependence. J Appl Economet 22(2):265-312. https://doi.org/10.1002/jae.951

Pesaran MH (2015) Testing weak cross-sectional dependence in large panels. Economet Rev 34(6-10):1089-1117. https://doi.org/10. 1080/07474938.2014.956623

Pham NM, Huynh TLD, Nasir MA (2020) Environmental consequences of population, affluence and technological progress for European countries: a Malthusian view. J Environ Manage 260:110143. https://doi.org/10.1016/J.JENVMAN.2020.110143

Pirgaip B, Dinçergök B (2020) Economic policy uncertainty, energy consumption and carbon emissions in G7 countries: evidence from a panel Granger causality analysis. Environ Sci Pollut Res 27(24):30050-30066. https://doi.org/10.1007/ s11356-020-08642-2

Rahmane A, Benelbar M, Traich M (2021) The nexus between sustainable energy and ecological footprint : evidence from Algeria. Sustain Sci Pract Policy 17(1):323-333. https://doi.org/10. 1080/15487733.2021.1946298

Rigobon R, Sack B, Rigobon R, Sack B (2005) The effects of war risk on US financial markets. Journal of Banking \& Finance, 29(7), 1769-1789. Retrieved from https://econpapers.repec.org/ RePEc:eee:jbfina:v:29:y:2005:i:7:p:1769-1789

Ulucak R, Khan SU (2020) Determinants of the ecological footprint: role of renewable energy, natural resources, and urbanization. Sustain Cities Soc 101996. https://doi.org/10.1016/j.scs.2019. 101996

Usman M, Hammar N (2021) Dynamic relationship between technological innovations, financial development, renewable energy, and ecological footprint: fresh insights based on the STIRPAT model for Asia Pacific Economic Cooperation countries. 15519-15536

Wackernagel M, Rees W (1998) Our ecological footprint: reducing human impact on the earth

Wang Z, Danish, Zhang B, Wang B (2018) The moderating role of corruption between economic growth and $\mathrm{CO} 2$ emissions: evidence from BRICS economies. Energy 148:506-513. https:// doi.org/10.1016/j.energy.2018.01.167

Westerlund $\mathbf{J}$ (2007) Testing for error correction in panel data. Oxford Bull Econ Stat 69(6):709-748. https://doi.org/10.1111/j. 1468-0084.2007.00477.x

Yu J, Shi X, Guo D, Yang L (2021) Economic policy uncertainty (EPU) and firm carbon emissions: evidence using a China provincial EPU index. Energy Econ 94:105071. https://doi.org/10. 1016/j.eneco.2020.105071

Zakari A, Adedoyin FF, Bekun FV (2021) The effect of energy consumption on the environment in the OECD countries: economic policy uncertainty perspectives. Environ Sci Pollut Res 28(37):52295-52305. https://doi.org/10.1007/ s11356-021-14463-8

Publisher's note Springer Nature remains neutral with regard to jurisdictional claims in published maps and institutional affiliations. 